3. Кулагина Е.Ю. Оценка биоклиматической комфортности территории Центрального федерального округа. // диссертация ... кандидата биологических наук: 03.02.08. Владимир. гос. ун-т им. Александра Григорьевича и Николая Григорьевича Столетовых. - Владимир, 2013. - с. 149.

4. Liu, Zhengyu. Dynamics of Interdecadal Climate Variability: A Historical Perspective // Journal of Climate, 2011. T. 25 (6). pp. 1963-95. doi:10.1175/2011JCLI3980.1. ISSN 0894-8755

5. Thomas C.D. et all, Extinction risk from climate change // Nature, 2004 - V. 427, №6970. - pp. 145-148.

6. Краснощёков А.Н., Кулагина Е.Ю., Трифонова Т.А. Оценка биоклиматической комфортности территории (на примере Центрального Федерального округа РФ) // Проблемы региональной экологии, 2013. - №3. - с. 46-50.

\title{
Денисова Ю.В. \\ Редкие земли в цирконе Кожимского массива (Приполярный Урал)
}

Институт геологии Коми НЦ УрО РАН

(Россия, Сыктывкар)

doi: $10.18411 / \mathrm{j}-06-2021-97$

\section{Аннотация}

В данной работе представлены результаты редких земель в акцессорном цирконе из Кожимского гранитного массива (Приполярный Урал). Определены медиальные значения содержаний редких земель по каждому морфологическому типу циркона, встречаемому в изученных гранитах. Выявлено отсутствие Tb, Ho, Tm во всех типах кожимского циркона. Дефицит этих TR указывает на высокую температуру и активную роль кислорода на всех этапах гранитогенеза. Проведено нормирование полученных составов по хондриту McDonough и Sun. Полученный результат показывает, что накопление редкоземельных элементов происходило постепенно в течении всего периода формирования гранитов.

Ключевые слова: циркон, гранит, редкие земли, Кожимский массив, Приполярный Урал.

\section{Abstract}

This paper presents the results of rare earths in accessory zircon from the Kozhim granite massif (the Subpolar Urals). The medial values of rare earths for each morphological type of zircon are determined. The absence of $\mathrm{Tb}, \mathrm{Ho}$, and $\mathrm{Tm}$ was found in all types of the Kozhim zircon. The lack of these TR indicates a high temperature and an active role of oxygen at all stages of granitogenesis. Normalization of the obtained compositions for McDonough and Sun chondrite was carried out. The presented result shows that the accumulation of rareearth elements occurred gradually during the entire period of granite formation.

Keywords: zircon, granite, rare earths, the Kozhim massif, the Subpolar Urals.

\section{Введение}

Геохимия редкоземельных элементов позволяет существенно дополнить информацию при решении многих вопросов генезиса магматических горных пород, гидротермально-метасоматических процессов, процессов рудообразования. Поведение этих элементов и в минералах является важным показателем их эволюции. Характер накопления TR напрямую связан с составом, температурой, кислотностьющелочностью, окислительно- восстановительным потенциалом и др. минералообразующей среды. Все это позволяет на основе изучения поведения TR элементов получить более детализированную информацию по отдельным этапам генезиса породы. Целью представленной работы является изучение распределения редкоземельных элементов в цирконе Кожимского гранитного массива (Приполярный Урал). 


\section{Объект исследования}

Кожимский массив, обнажающийся в сводовой части Ляпинского антиклинория, расположен в бассейнах ручьев Понью, Осею и Епкошор на левом и правом берегах р. Кожим. Составляющие массив гранитные тела относятся к одной межпластовой интрузии, прорывающей отложения пуйвинской свиты среднего рифея. Породы максимальной сохранностью первичной структуры и облика представляют собой плотные гнейсовидные породы розового цвета с хорошо выраженным зеленоватосерым оттенком. Минеральный состав гранитов представлен калиево-натриевым полевым шпатом (50\%), кварцем (30\%), плагиоклазом (15\%), мусковитом (3\%), биотитом $(2 \%)[5,6,8,9,10]$.

\section{Типоморфические особенности циркона Кожимского массива}

Среди цирконов Кожимского массива характерно наличие трех морфологических типов. Первый морфологический тип - светлоокрашенные (от бесцветного до светло-желтого) прозрачный короткопризматический циркон. Габитус кристаллов обусловлен развитием призмы (110) и дипирамиды (111). Размер кристаллов 0,05 - 0,25 мм. Коэффициент удлинения 0,6 - 1,2. Содержание цирконов первого типа оставляет 85 - 95 \% от общего объема этого минерала в породе. Темнокоричневый короткопризматический прозрачный циркон выделен во второй морфологический тип. Развиты грани (100), (110), присутствует (111) дипирамида. Размер таких кристаллов 0,1 - 0,25 мм. Коэффициент удлинения 0,8 - 1,3. Содержание цирконов второго типа в среднем 1 - 5 \% от общего объема минерала в породе. Третий морфологический тип составляют светлоокрашенные (от бесцветного до светложелтого) прозрачные цирконы длиннопризматического габитуса. Размер кристаллов 0,5 - 0,9 мм, коэффициент удлинения 1,5 - 4,0. Габитус кристалла, обусловленный развитием граней (100), (110). Содержание циркона данного морфологического типа 1 $5 \%$ от общего состава содержания минерала в породе.

Согласно ранее проведенному исследованию, на основе средних содержаний гафния автором была определена последовательность выделения каждого морфологического типа изученного циркона, что позволило определить характерный морфотип минерала для каждого этапа гранитогенеза II (1,19 мас. \%) (ранний этап) $\rightarrow$ III (1,31 мас. \%) $\rightarrow$ I тип (1,37 мас. \%) (поздний этап) $[1,2,3]$.

\section{Особенности распределения редких земель в цирконе Кожимского массива}

Для каждого вышеописанного морфологического типа акцессорного циркона были определены медиальные содержания редкоземельных элементов (таблица 1). Главным объединяющим признаком для всех изученных морфотипов циркона является отсутствие таких элементов, как Tb, Но, Тm. Это указывает на высокую температуру материнского расплава и, соответственно, более активную роль кислорода в течении всего гранитогенеза. На начальном этапе формировании кожимских гранитов это привело к образованию оксидов этих редких элементов, на завершающем - к кристаллизации монацита. Проведенное нормирование полученных данных по хондриту McDonough и Sun [12] (рис. 1) показало, что наиболее насыщенный редкими землями циркон относится к I типу, кристаллизовавшемуся на завершающей стадии гранитогенеза. Для этого типа циркона характерно повышенное содержание почти всех выявленных в минерале редких земель за исключением $\mathrm{Pr}$, Eu. II морфологический тип циркона, образовавшийся на ранней стадии формирования гранитов Кожимского массива, преимущественно насыщен тяжелыми редкоземельными элементами (в 2-3 раза относительно хондрита по McDonough и Sun), причем наиболее сильно увеличены содержания $\mathrm{Yb}$ и Lu. Циркон обладает физико- химической устойчивостью, что позволяет на основе химического анализа минерала проследить изменения в минералообразующей среде. Так, графики распределения REE для кожимского циркона показывают равномерное насыщение редкими землями гранитов в процессе становления массива[4, 7, 11]. 
Таблица 1.

Медиальные содержания REE для ичиркона Кожимского гранитного массива и нормализация по хондрит (Cl no McDonough, Sun).

\begin{tabular}{|c|c|c|c|c|c|c|c|c|c|c|c|c|c|}
\hline \multirow{4}{*}{$\begin{array}{l}\text { Элемен } \\
\text { т, ppm }\end{array}$} & \multirow{2}{*}{\multicolumn{6}{|c|}{$\begin{array}{c}\text { Медиальные содержания REE } \\
\text { Морфологический тип }\end{array}$}} & \multirow{4}{*}{$\begin{array}{l}\mathrm{Cl}, \\
\mathrm{ppb}\end{array}$} & \multirow{2}{*}{\multicolumn{6}{|c|}{$\begin{array}{c}\text { Нормализация по хондрит } \\
\text { Морфологический тип }\end{array}$}} \\
\hline & & & & & & & & & & & & & \\
\hline & \multicolumn{2}{|c|}{ I } & \multicolumn{2}{|c|}{ II } & \multicolumn{2}{|c|}{ III } & & \multicolumn{2}{|c|}{ I } & \multicolumn{2}{|c|}{ II } & \multicolumn{2}{|c|}{ III } \\
\hline & ц & к & ц & К & ц & К & & ц & К & ц & к & ц & К \\
\hline $\mathrm{La}$ & 0,2 & 0,28 & 0,02 & 0,08 & 0,11 & 0,15 & 237 & 0,93 & 1,18 & 0,08 & 0,34 & 0,46 & 0,63 \\
\hline $\mathrm{Ce}$ & 0,3 & 0,42 & 0,22 & 0,24 & 0,35 & 0,36 & 613 & 1,60 & 1,77 & 0,93 & 1,01 & 1,48 & 1,52 \\
\hline $\operatorname{Pr}$ & 0,2 & 0,24 & 0,08 & 0,11 & 0,18 & 0,19 & 92,8 & 0,93 & 1,01 & 0,34 & 0,46 & 0,76 & 0,80 \\
\hline $\mathrm{Nd}$ & 0,2 & 0,29 & 0,09 & 0,13 & 0,19 & 0,22 & 457 & 1,05 & 1,22 & 0,38 & 0,55 & 0,80 & 0,93 \\
\hline $\mathrm{Sm}$ & 0,3 & 0,42 & 0,19 & 0,19 & 0,34 & 0,36 & 148 & 1,60 & 1,77 & 0,80 & 0,80 & 1,43 & 1,52 \\
\hline $\mathrm{Eu}$ & 0,1 & 0,21 & 0,09 & 0,09 & 0,15 & 0,16 & 56,3 & 0,76 & 0,89 & 0,38 & 0,38 & 0,63 & 0,68 \\
\hline $\mathrm{Gd}$ & 0,4 & 0,53 & 0,31 & 0,35 & 0,42 & 0,45 & 199 & 1,94 & 2,24 & 1,31 & 1,48 & 1,77 & 1,90 \\
\hline $\mathrm{Tb}$ & 0 & 0 & 0 & 0 & 0 & 0 & 36,1 & 0 & 0 & 0 & 0 & 0 & 0 \\
\hline Dy & 0,5 & 0,55 & 0,29 & 0,34 & 0,42 & 0,46 & 246 & 2,19 & 2,32 & 1,22 & 1,43 & 1,77 & 1,94 \\
\hline Ho & 0 & 0 & 0 & 0 & 0 & 0 & 54,6 & 0 & 0 & 0 & 0 & 0 & 0 \\
\hline Er & 0,5 & 0,62 & 0,38 & 0,41 & 0,52 & 0,55 & 160 & 2,41 & 2,62 & 1,60 & 1,73 & 2,19 & 2,32 \\
\hline $\mathrm{Tm}$ & 0 & 0 & 0 & 0 & 0 & 0 & 24,7 & 0 & 0 & 0 & 0 & 0 & 0 \\
\hline $\mathrm{Yb}$ & 0,7 & 0,74 & 0,48 & 0,53 & 0,65 & 0,68 & 161 & 3,00 & 3,12 & 2,03 & 2,24 & 2,74 & 2,87 \\
\hline $\mathrm{Lu}$ & 0,6 & 0,69 & 0,46 & 0,49 & 0,63 & 0,64 & 24,6 & 2,83 & 2,91 & 1,94 & 2,07 & 2,66 & 2,70 \\
\hline$\sum$ & 4,5 & 4,99 & 2,61 & 2,96 & 4,00 & 4,22 & - & - & - & - & - & - & - \\
\hline
\end{tabular}

Примечание. Микрозондовый анализ выполнен в ЦКП Геонаука Института геологии Коми НЦ УрО РАН (комплекс Vеgа3 Tеscan, аналитик Шевчук С. С.). Содержание редкоземельного элемента определено в центральной (u) или краевой (к) зоне циркона.

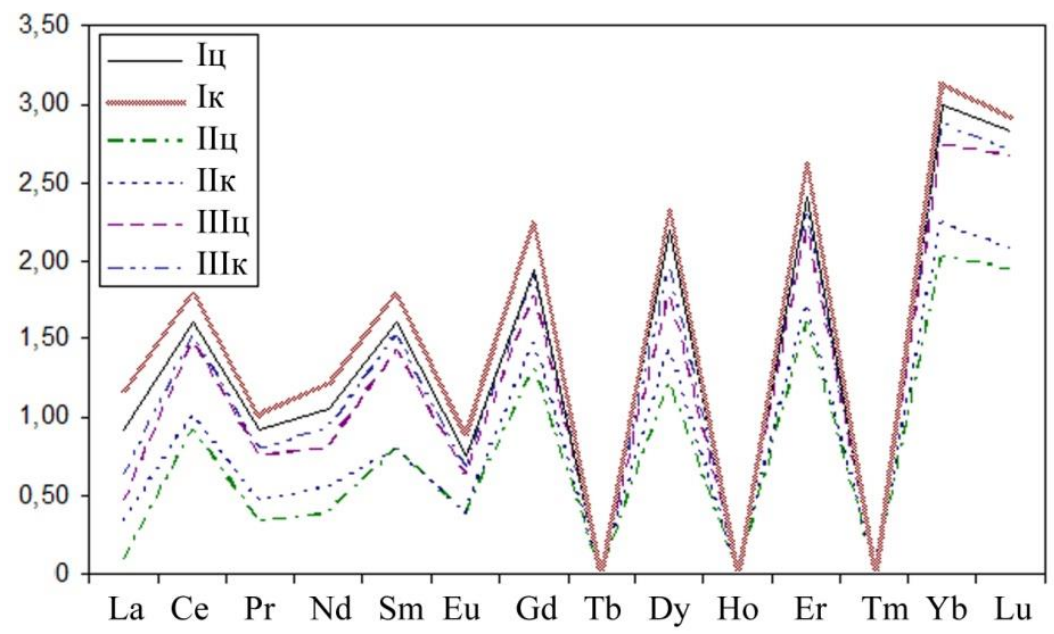

Puc. 1. Нормированные спектры распределения REE (циркон/хондрит по McDonough, Sun) для ичикона Кожимского гранитного массива.

Все диаграммы характеризуется преобладанием редкоэлементной Ү- группы над $\mathrm{Ce}-$ группой, а так же четко проявленными положительной Се и отрицательной Еu аномалии. Превалирование Y- группы над Се- группой связано с тем, что на начальных этапах формирование породы часть редкоземельных элементов (преимущественно цериевой группы) входит в состав плагиоклазов в качестве изоморфной примеси, а элементы Се- группы из остаточных расплавов образуют алланит. Элементы иттриевой группы на начальных этапах входят в составе роговой обманки, а в остаточных расплавах могут отмечаться в виде изоморфной примеси в ряде акцессорных минералов, преимущественно - в цирконе. Положительная Се- аномалия 
контролируется летучестью (фугутивностью) кислорода, Увеличение этого пика является показателем изменения степени окисления химических элементов в магматическом расплаве, что приводит к смене выделяемых минералов. Так, время кристаллизации циркона первого типа наиболее благоприятно для формирования магнетита и ильменита из расплава, так как на завершающей этапе гранитогенеза наибольшая активность кислорода, что позволяет переводить железо из силикатов в оксидную фазу. Дефицит $\mathrm{Eu}$ сравнительно небольшой, но достаточно четко выраженный для всех морфологических типов кожимского циркона. Причем глубина европиевой аномалии, характеризующая отношение $\mathrm{Eu}^{2+} / \mathrm{Eu}^{3+}$ увеличивается от Іц и Ік (ранний этап гранитогенеза) до ІІц и ІІк (поздний этап гранитогенеза). Причиной появления этой аномалии считается влияние кристаллизационной дифференциации на процессы преобразования кислых расплавов, в результате которого в расплаве происходило активное удаление (фракционирование) полевых шпатов.

\section{Заключение}

Изучение редких земель в составе акцессорного циркона Кожимского гранитного массива (Приполярный Урал), представленного тремя морфологическими типами, показало, что для всех рассмотренных минералов характерно отсутствие Тb, Но, Tm, указывающие на высокую температуру и активную роль кислорода на всех этапах гранитогенеза. Нормирование по хондриту McDonough и Sun состава редких земель для всех типов циркона, выявило постепенно накопление редкоземельных элементов в течении всего периода формирования гранитов. Активную роль кислорода подтверждает и положительная Се- аномалия, отмеченная на нормированной по хондриту диаграмме, показывающая так же увеличение степени окисления химических элементов в магматическом расплаве со временем. Завершающий этап гранитогенеза характеризуется наибольшей активностью кислорода, что делает этот временной отрезок наиболее благоприятным для формирования магнетита и ильменита из расплава. Дефицит Еu так же усиливается со временем, что указывает на увеличение влияния кристаллизационной дифференциации на процессы преобразования кислых расплавов.

\section{$* * *$}

1. Денисова Ю. В. Типоморфические и типохимические особенности акцессорных цирконов гранитоидов Приполярного Урала // Вестник Института геологии Коми НЦ УрО РАН, Сыктывкар, № 5, 2014. С. 9 - 16.

2. Денисова Ю. В. Петрогенетическое значение $\mathrm{ZrO} 2 / \mathrm{HfO} 2$ отношения в акцессорном цирконе гранитов Приполярного Урала // Вестник Института геологии Коми НЦ УрО РАН, Сыктывкар, № 2, 2015. C. 23 - 31.

3. Денисова Ю. В. Термометрия циркона из гранитоидов Приполярного Урала // Вестник Института геологии Коми НЦ УрО РАН, Сыктывкар, № 12, 2016. С. 37 - 44.

4. Ляхович В.В. Редкие элементы в акцессорных минералах гранитоидов. М.: Недра, 1973. 310 с.

5. Махлаев Л. В. Гранитоиды севера Центрально- Уральского поднятия (Полярный и Приполярный Урал). Екатеринбург: УрО РАН, 1996. 189 с.

6. Пыстин А. М., Пыстина Ю. И. Метаморфизм и гранитообразование в протерозойскораннепалеозойской истории формирования Приполярноуральского сегмента земной коры // Литосфера. 2008. № 11.

7. Скублов С. Г. Геохимия редкоземельных элементов в породообразующих метаморфических минералах. СПб.: Наука, 2005. 147 с.

8. Фишман М. В., Голдин Б. А. Гранитоиды центральной части Приполярного Урала. М.- Л.: АН CCCP, 1963. $105 \mathrm{c}$.

9. Фишман М. В., Юшкин Н. П., Голдин Б. А., Калинин Е. П. Минералогия, типоморфизм и генезис акцессорных минералов изверженных пород севера Урала и Тимана. М.- Л.: Наука, 1968. 252 с.

10. Фишман М. В., Юшкин Н. П., Голдин Б. А., Калинин Е. П. Основные черты магматизма и метаморфизма в центральной части Приполярного и Полярного Урала // Геохимия, минералогия и петрография севера Урала и Тимана. Сыктывкар, 1969. С. 7 - 25.

11. Шардакова Г. Ю., Шагалов Е. С. Распределение редких элементов в породообразующих и акцессорных минералах гранитоидов Урала / Геохимия, 2004, № 3, С. 254-269.

12. McDonough W., Sun S. S. The composition of the earth. Chem. Geol. № 120. 1995. P. $223-253$. 